\title{
"ENCONTRÉ TRES PALABRAS PARA JUGAR HOY: EXACTO, EXCÉNTRICO, EXTREMO”: EL EFECTO PERFORMÁTICO EN LOS CUENTOS DE NADINE ALEMÁN
}

\author{
Cristián Basso Benelli \\ Universidad Metropolitana de Ciencias de la Educación, Chile
}

\begin{abstract}
RESUMEN: La narrativa patagónica argentina actual tiene en Nadine Alemán (Esquel, 1977) a una de sus voces más sugerentes y creativas. Esta afirmación se sustenta en su capacidad de construir un imaginario narrativo que produce efectos performáticos, derivados de la confluencia y evocación de otros lenguajes que se advierten en la recepción literaria de 17 simples cuentos (2006) y de El cura y la sucia (2012). Los límites tradicionales que suelen restringir lo literario a un campo específico de acción crítica parecen, en consecuencia, desdibujarse. Así, lo performático - en cuanto "lente metodológico", según Diana Taylor- se transforma en una posibilidad cierta que amplía perspectivas de acercamiento a esta propuesta escritural hispanoamericana.
\end{abstract}

PALABRAS CLAVE: narrativa patagónica argentina, Nadine Alemán, efecto performático, cuentos, lenguajes

"I found three words to play with today: exact, eccentric, extreme": the performance effect in Nadine Alemán's stories

\begin{abstract}
Current Argentinean Patagonian narrative possesses Nadine Alemán (Esquel, 1977) as one of its most suggestive and creative voices. This assertion is based on her capacity to construct a narrative imaginary that produces performance effects, derived from the confluence and evocation of other languages that can be found in the literary reception of 17 simples cuentos (2006) and of El cura y la sucia (2012). The traditional boundaries that tend to restrict literature to a specific field of critical action seem, in consequence, to become fuzzy. Thus, performance - as a "methodological lense", according to Diana Taylor- is made into a certain possibility that widens perspectives to approach this Spanish American writing proposal.
\end{abstract}

KEYWORDS: Argentine Patagonia narrative, Nadine Alemán, performance effects, short stories, languages 


\section{INTRODUCCIÓN}

La literatura hispanoamericana reciente se ha enriquecido con nuevas propuestas de autoras que en el último decenio han ido consolidando imaginarios discursivos de interés lector y crítico. Entre ellas, las narrativas de Selva Almada, Alejandra Costamagna, Mariana Enríquez, Valeria Luiselli, Guadalupe Nettel, Samanta Schweblin o Mónica Ojeda resultan ya familiares en el panorama literario actual. Paralelamente, han surgido otras apuestas creativas que, gracias a la autoedición, la ampliación del mercado editorial independiente y los variados espacios de difusión virtuales, han visibilizado escrituras que en otros momentos históricos habrían quedado al margen de la atención crítica, contribuyendo con ello al desigual canon filológico.

En dicho contexto, surge la escritura de Nadine Alemán como una de las voces más sugerentes y creativas de la actual narrativa patagónica argentina. Esta afirmación se sustenta en su capacidad de construir un imaginario narrativo que reúne rasgos estilísticos distintivos de trasfondo patagónico y la narración de raigambre audiovisual que produce efectos performáticos derivados de su particular modo de narrar, que, a su vez, evoca la coexistencia del cuerpo textual con otros lenguajes artísticos en sus relatos publicados hasta hoy.

Nacida en 1977 en Esquel (Patagonia argentina), Nadine Alemán es licenciada en Cine y Televisión por la Universidad Nacional de Córdoba; realizadora de proyectos audiovisuales en Argentina y Chile; guionista de La tierra de mis hijos, largometraje que narra la travesía de los colonos galeses en la cordillera de Los Andes; ${ }^{1} \mathrm{y}$, actualmente, académica de Artes Audiovisuales en su ciudad natal. A la fecha, es autora de 17 simples cuentos (2006) y El cura y la sucia (2012), dos volúmenes de cuentos breves de los que nos ocuparemos de aquí en adelante, algunos de los cuales se han traducido al árabe, inglés y alemán. ${ }^{2}$ Asimismo, editó Letal Intensidad (2009), poemario en que alterna el verso rítmico breve de sentencia amorosa con letras de tango.

El presente artículo indaga en el efecto performático que resulta de la recepción literaria de sus cuentos. El interés central está puesto sobre aquellos en que lo simple y lo complejo convergen en un instante ficcional de "escenificación literaria", entendido como acto escritural que sugiere la performance. A partir de dicho acto, Alemán construye el trasfondo de su propuesta creativa, instalada en el contexto de obras literarias escritas por autoras

${ }^{1} \mathrm{Al}$ momento de redactar este artículo, la película no ha sido rodada por falta de financiación.

${ }^{2}$ Si bien los libros de cuentos de Nadine Alemán no han sido traducidos hasta ahora íntegramente a dichas lenguas, sus relatos han despertado interés entre profesores de español como lengua extranjera que imparten clases en Alemania, Reino Unido y Marruecos, especialmente en el Instituto Cervantes de estos países, quienes han traducido al alemán, al inglés y al árabe algunos de ellos para que sean estudiados y circulen, aunque informalmente, entre sus estudiantes. Las versiones traducidas al inglés de "Bianca encierra" (2010), "La puerta 202" (2011) y "La invasión de la señora Grimaraes" (2014) están disponibles en el blog que la autora mantiene desde 2008: http://nadinealeman.blogspot.com. 
patagónicas argentinas que, en el tiempo reciente, han venido estableciendo una literatura de interés latinoamericano.

\section{SUPUESTOS CRÍTICOS}

Desde la perspectiva crítica, resulta pertinente abordar la producción literaria de Nadine Alemán a partir de supuestos teóricos provenientes de la teoría de la recepción, la estrategia deconstructivista y los estudios sobre performance. El objetivo de ese abordaje es poner de manifiesto los rasgos característicos de su apuesta escritural.

En general, los sistemas críticos de la teoría de la recepción (Roman Ingarden, 2005; Wolfgang Iser, 1989; Jonathan Culler, 2014; Terry Eagleton, 2016, y Hans-Robert Jauss, 2002) han propuesto enfoques centrados en el lector. Desde esa perspectiva, han concebido la lectura como una actividad en la cual se participa propositivamente del texto literario para ocuparse de los sentidos sugeridos por las fisuras, grietas, vacíos e indeterminaciones que lo constituyen, posibilitando la exploración analítica de la recepción literaria a partir de la confluencia de distintas disciplinas. A este respecto, Iser sostiene que "al desplegarse la lectura mediante previsiones y retroacciones, adquiere el carácter de un acontecimiento, lo cual produce la supresión de cercanía de lo que está vivo” (1989, 161), abstrayéndonos, cautivándonos y produciendo efectos estéticos derivados de la receptividad, porque "la obra de arte es la constitución del texto en la conciencia del lector" (Iser, 1989, 149).

Por su parte, la deconstrucción derridiana, en cuanto estrategia, ofrece un prisma alternativo en el que un architexto deviene en texto. Surgen, en consecuencia, espacios donde las referencias asumen posibles exploraciones para abordar el carácter inacabado del sentido. Por este motivo, en la experiencia interpretativa no sería extraño seguir un trayecto de análisis heterogéneo que considere las huellas de percepción en diversas direcciones que permitan el acceso a otras claves de sentido textual (Derrida, 1989, 310). De este modo, la lectura se transforma en recorrido, más que en una continuidad metodológica amparada, en tanto tradición "logocéntrica", en un modelo preexistente que funcione a priori como guía de una lectura lineal.

El recorrido deconstructivista parte de la convicción de que lo textual no dice solo lo que muestra, sino que reproduce huellas que permiten recorrerlo en libertad, a través de mecanismos y modos de desmantelamiento de sentidos que surgen de la desestabilización de oposiciones binarias propias de la cultura occidental. Tal condición sugiere reflexiones teóricas cuyos frutos han hecho manifiesta la tendencia a disociar las categorías de sujetoobjeto, lector-autor, lector-lectura o texto-lector para luego deconstruirlas con el fin de acceder a nuevas experiencias de acercamiento al hecho literario, tal como ha ocurrido con los enfoques críticos posestructuralistas (Selden, Widdowson y Brooker, 2001, 185-314).

En cuanto a la concepción de performance se refiere, la crítica especializada (Schechner, 2006; Taylor, 2017; Debord, 2014, entre otros) ha discutido acerca de la distinción del término con respecto de su propia naturaleza (acto de realización artístico-cultural) y a la alternativa de emplearla como enfoque de estudio (análisis del hecho artístico). Congrega, en efecto, 
expresiones y recursos diversos en un momento único de realización artística, en el que el cuerpo suele asumirse como eje referencial de una puesta en práctica que transforma el lenguaje en acción, evocación y experimentación. Por lo tanto, aparece como una estrategia analítica posible que asocia expresiones artísticas y lenguajes diversos.

Dada la amplitud de su significación, se ha optado por emplear en este estudio el término performático (adjetivación), considerando la distinción que J. L. Austin (1996) propone para distinguirlo de lo performativo (efectos y resultados de actos de habla), aplicable a múltiples realizaciones del lenguaje.

Según Diana Taylor (2011), dichos actos han sido parte de la base cultural de los pueblos, en especial los del continente americano, pues fueron estos quienes los cultivaron como expresión natural de la ritualidad de la experiencia común, la identidad y la denuncia ante la opresión de sistemas de dominación colonizantes. A su vez, plantea una premisa fundamental para los fines de esta investigación: "Reconocer la performance como un enfoque válido de análisis que contribuye a nuestra comprensión de la práctica corporalizada como una episteme y como una praxis, una forma de conocer, así como de almacenar y transmitir el saber cultural y la identidad" (Taylor, 2017, 384).

De lo anterior surgen las siguientes preguntas relativas al vínculo existente entre la recepción de la obra narrativa de Alemán y lo performático: ¿qué caracteriza a sus relatos para afirmar que producen, tras su recepción, un efecto similar al de la performance? ¿Dicho efecto se evidencia en ambas compilaciones de cuentos? ¿Cómo se comprueba? Estos interrogantes no se asientan en la idea de que sus cuentos sean en sí mismos performance o formen parte de un acto de intervención artística que los integre, sino que sugieren dicho efecto como resultado de su recepción literaria. Hecha la aclaración, estas preguntas podrán responderse en el desarrollo sucesivo de este estudio, no sin antes establecer qué se entenderá por performance.

Performance es un término polisémico de considerable trayectoria conceptual (Taylor, 2011). Ha sido investigado preferentemente en cuanto realización, teatralidad, corporalidad manifiesta, espectáculo, escenificación y acción artística en vivo. No obstante, su versatilidad definitoria permite concebirlo como expresión artística en la cual variadas formas y lenguajes coinciden en un solo acto que los reúne con un propósito expresivo y artístico, usualmente de índole política y sociocultural.

Asimismo, de su naturaleza abierta se han extraído nociones que lo caracterizan como realización sujeta a ese momento único que la distingue, y en el que tanto espectador como acto performático se interrelacionan "en directo", intercambiando a la vez palabra, cuerpo y expresión, manifiestos en un aquí y un ahora. Es por ello que el tempo define a la performance, al ser cuerpo hecho voz -o viceversa-: una suerte de cuerpo que habla y se convierte en tránsito, en flujo comunicante del que emanan sensaciones, emociones, ideas y, por supuesto, efectos.

Diana Taylor y Marcela Fuentes reunieron en Estudios avanzados de performance (2011) esclarecedores antecedentes que aportaron una revisión de la evolución del concepto, sobre 
todo en lo relativo al carácter de artivismo que contiene toda intervención artística ejecutada en espacios públicos y privados, en tanto acto artístico y político se refiere.

En la introducción a dicho estudio, Taylor señala que "la performance crea complicaciones prácticas y teóricas tanto por su ubicuidad como por su ambigüedad" (2011, 7), porque "el campo de los estudios de la performance trasciende fronteras disciplinarias para estudiar fenómenos más complejos con lentes metodológicos más flexibles que provienen de las artes, humanidades y ciencias sociales" (Taylor, 2011, 13).

En consecuencia, el término está premunido de significaciones que acercan y desdibujan sus propios límites conceptuales para ofrecerse como alternativa válida desde la cual concebir, analizar y experimentar el arte, entre los cuales contamos el literario. La apertura terminológica nos conduce a reflexionar sobre la experiencia estética como acceso a la multiplicidad de opciones con las cuales podemos establecer contactos cuando de interactuar con el hecho literario o artístico se trata, porque "la performance como lente permite a los críticos explorar no solo eventos aislados y casos límite, sino también escenarios que componen los imaginarios individuales y colectivos" (Taylor, 2017, 384).

Las experiencias perceptuales, antecesoras de las conceptuales, posibilitan la captación sensorial del arte, ya sea que irradien desde un objeto artístico, desde una representación artístico-corporal, desde una puesta en escena o desde el proceso creativo que la originó. En definitiva, la percepción motivadora inicial promueve las recreaciones estimuladas por la fuente artística, tal como lo indica la académica española Matilde Carrasco Barranco:

[...] la dimensión estética es común y caracteriza por ello a todas las obras de arte, y asimismo la capacidad que tengan de generar experiencias valiosas (en las que nuestra sensibilidad y nuestras capacidades cognitivas y afectivas conjuntamente, ya sean excitadas o a menudo desafiadas) [...] siempre ha jugado, y seguirá jugando, un papel importante en nuestra relación con el arte $(2017,68)$.

Dicha dimensión artística, tanto en 17 cuentos simples como en El cura y la sucia, de Nadine Alemán, muestran cómo una situación narrativa puede tornarse movimiento, sonoridad, luz, imagen y cuerpo. En otros términos, se transforma en convergencia de lenguajes manifiestos o aludidos por la palabra y expresados desde el ejercicio deconstructivo que permite ampliar el "leer literariamente". Sin embargo, este efecto es también resultado de una estética y una búsqueda que se comprenden en el contexto de la literatura patagónica argentina en la que se originan.

\section{LA NARRATIVA DE NADINE ALEMÁN EN LA LITERATURA PATAGÓNICA ARGENTINA}

Abordar la literatura patagónica argentina más allá de la consabida condición geográfica regional (Mellado, Bittar, Casini, Polli y Saint-André, 1996, 49-57) requiere despojarse de criterios que calcen con la comprobación de un determinado cúmulo de rasgos identitarios asociados a una literatura de naturaleza fundacional. El propósito será, por lo tanto, asumir 
la problemática que significa lo patagónico como constructo cultural, cuyo aporte desde lo literario invita a superar concepciones reduccionistas que la traten únicamente desde la mirada local. A este respecto, la poeta e investigadora Luciana Andrea Mellado sostiene que dichas limitantes se originan en el interés de una cultura hegemónica por categorizar las literaturas nacionales sin reparar en la diversidad que las complejiza:

Las aldeas se localizan primordialmente en el espacio de la nación, cuya imagen más difundida la propone como una aldea mayor, el singular continente de plurales contenidos. La Patagonia complejiza esta idea, al inscribirse, sin renunciar a las afiliaciones nacionales, en una pertenencia doble y transnacional: se trata de una región geocultural argentina y chilena. Esto multiplica las complejidades de abordaje con las herramientas de la teoría y crítica literaria del constructo de la literatura nacional, como principio modelizante y axiológico de saberes, textos, cánones y también identidades, trazadas desde una centralización cultural en posición hegemónica (Mellado, 2015, 70).

Muchas veces, dicho sentido de pertenencia impide visibilizar otras vías que permitan transitar sobre las distintas manifestaciones artístico-culturales, rotulándolas en una suerte de tipología arbitraria que confirma el conjunto de un producto cultural digerido por la cultura hegemónica (Mellado, 2015, 67).

En 2012 el poeta chubutense Jorge Eduardo Vives constató la escasa producción de estudios académicos que pudiesen relevar la existencia y valoración de la literatura patagónica. Asimismo, cuestionó dicha denominación, amparándose en lo desconocidos que eran todavía sus escritoras y escritores, para lo cual propuso tres principios de caracterización identitaria:

[...] en un principio, es una narrativa cuyas ficciones transcurren en la Patagonia, luego que esté escrita por autores patagónicos nacidos o "adoptados" en dichas tierras australes, y, finalmente, que cultivan temáticas cuyos elementos preferentes y comunes provenientes de los rasgos propios de la región de los cuales se recoge el "acervo geográfico y humano" que la distingue (Vives, 2012, párr. 2).

En dicho contexto territorial, añade Vives, prolifera una naturaleza particular que explica, en parte, el estilo realista de la narrativa patagónica, matizada por la alternancia del "paisaje humano" y en cuya composición participan tanto los colonos como los habitantes originarios, quienes han desarrollado sus vidas en el terreno de la zona. Ese espacio es, de igual modo, determinante de una forma de ver y concebir el mundo: "mar, meseta, cordillera, nieve, viento, soles quemantes, horizontes distantes, espacios enormes, cielos brillantes y coloridos" (Vives, 2012, párr. 3).

Tanto en 17 cuentos simples como en El cura y la sucia, si bien se asumen y refieren los rasgos patagónicos anteriores, los relatos amplían y enriquecen el trasfondo de sus historias al situar sus personajes en espacios que trascienden lo local desde dos ejes de acción narrativa: el secreto como portabilidad creativa y lo perverso como consecuencia del secreto. 


\section{EL SECRETO COMO PORTABILIDAD CREATIVA EN 17 SIMPLES CUENTOS}

En el prólogo a 17 simples cuentos, Luis Nieto desglosa una mirada crítica y valorativa del conjunto de relatos en los que ya, aún muy joven, su autora "maneja temas escabrosos con solvencia” (Alemán, 2006, 10), porque “[...] escribe al borde de lo tolerable, desde su Patagonia, desde el viento eterno de la cordillera, desde los bailes del sábado por la noche en su Esquel donde en ocasiones surgen sus personajes, desde su Vintter, donde la nieve envuelve las aisladas casas durante meses, nos cuenta, con narraciones muy breves, cómo es ese mundo" (Alemán, 2006, 13).

A partir de esta última aseveración, el escritor uruguayo establece una referencia esencial para esta recepción lectora: el secreto como fuente desde la cual emana la construcción de la identidad del hecho narrativo. Es en él donde habita el núcleo de la narración, es decir, en la acción premeditada y realizada que da vida a las historias. Del ocultamiento o la develación de un secreto provienen las decisiones, confesiones, obsesiones y el cambio de destino de los personajes. Su presencia es relevante para el desarrollo de las historias, tal como ocurre en "Una mujer digna", cuya protagonista decide cambiar su destino, confesándole a su marido la historia amorosa paralela que vive junto a su joven amante: "Acostumbrada a disimular, disimulo. Dejo mi bolso en el lavadero, paso por el escritorio y veo la carta arriba [...] cambio una carta por otra, como una guionista tratando de cambiar el rumbo de sus personajes, en una yo soy la culpable, en la otra es Ernesto el responsable” (Alemán, 2006, 42). Llama la atención que el personaje se compare con una guionista, rasgo que, por asimilación extratextual, no solo coincide con el oficio de la autora, sino que también ofrece al personaje la posibilidad de intervenir y alterar conscientemente el desarrollo de los hechos para manipularlos. En este sentido, la historia se escribe a la manera del guion por quien toma conciencia de que el destino puede ser resultado de un minucioso plan de cambio de piezas. Asimismo, en "Al fondo, los reptiles", la manipulación es más evidente cuando la relación de la protagonista con los demás personajes se basa en la extorsión, no sin antes darles la posibilidad de un cambio de rumbo: "Hay algo que creo darles a todos mis extorsionados y es la posibilidad de levantarse antes de que todo suceda y queden atados al secreto eternamente" (Alemán, 2012, 97).

Para Guiraud (2007), el secreto está relacionado con una práctica social que conflictúa al sujeto, aunque su fuerza "no se comprende solo como un discurso indirecto o una palabra retenida, sino como una práctica social, es decir, como una variedad de usos sociales que tienen su estética. Estos usos resultan de la palabra y el silencio, de la mentira y del travestismo, de la norma política y de la estrategia, de la identidad social, de la iniciación, del desvío, etcétera" (Giraud, 2007, 53).

El secreto motiva la acción narrativa, pero también la obstaculiza. En "El cordero", su protagonista dirá: "En otro momento, quizás de más chico, ante el reto de mi papá hubiera largado un insulto [...], pero ahora no, yo sabía muy bien que de un tiempo a esta parte la sola cercanía de su muerte, ya fuera de un cristiano o un animal, me paralizaba. Pero no podía 
explicarle eso a papá” (Alemán, 2006, 31). Los personajes, en definitiva, ocultan sus verdaderos deseos para adulterar la realidad.

Desde el secreto, además, se proyecta la serie de historias que vinculan la Patagonia natal como trasfondo con la apuesta escritural que indaga en emociones, deseos y fuerzas opuestas que motivan a los personajes. Así, el sujeto que se enfrenta y conflictúa en un contexto habitualmente adverso da origen a una sucesión de planos que ocultan intenciones, posibles de revelarse en la exactitud del avance de historias conmovedoramente elocuentes que hacen pensar en una secuencia de guion, como en "Bianca encierra":

Bianca encierra las pocas ovejas en el corral todas las tardes. Y vuelve al rancho con las piernitas envueltas en abrojos y temblando por el frío hostil de la cordillera. Bianca y su vida suspendida. Bianca con ese padre viejo y acabado que no le dio más vida que esa vida, llena de ausencias. Bianca y las estrellas. Pero ella sale inmutable cuando lo oye decir, a veces como única frase en todo el día: "iBianca, encierra!". Ella sale del rancho y encierra todo lo que puede (Alemán, 2006, 48).

A lo anterior se suma la idea del secreto como clave interpretativa del pensar, sentir y hacer de los personajes, convirtiéndose en directriz de sus destinos que vienen del pasado reciente o más atrás, desde la infancia. Así se evidencia, por ejemplo, en “El 202”, relato cuyo protagonista oculta una experiencia fantasmagórica de la niñez que, ya adulto, su hijo parece revivir: "Mi hijo tiene la misma edad que yo cuando llegué, y sigue haciendo el mismo recorrido que yo hacía, cuando sale y entra a nuestro departamento, y juro que, sin que yo le haya contado nada, he oído a mi hijo picar fuerte, muy fuerte la pelota cuando va, como hipnotizado por la luz de afuera, por el pasillo hacia la calle mientras yo trato de distraerme para no escuchar cómo se abre la puerta del 202" (Alemán, 2006, 25).

Para Juan Antonio Ramírez (1983, 79), "los significados secretos de nuestra vida surgen como un símil cinematográfico tan evidente que se nos sugiere atender más a la aparición de imágenes que a la de las palabras”. Esta afirmación se entronca con los recursos retóricos que caracterizan el lenguaje literario empleado en los relatos, entre los cuales la imagen poética cobra especial relevancia al conseguir efectos visuales inesperados, de asociación mental, similares a los que provocan las artes visuales y cinematográficas: "Hay un hombre aquí afuera en una hermosa carpa con forma de útero" (Alemán, 2012, 70).

Otra de las características de los relatos gira en torno al secreto oculto como portador de emociones, intenciones y acciones que contienen las verdaderas percepciones e intereses de los personajes, aludidas mediante imágenes y experiencias infantiles traumáticas, puesto que "por medio del secreto y de su reserva, exploramos las fronteras interpersonales, determinamos las esferas de intimidad y definimos la naturaleza de nuestras relaciones con los demás” (Blake, 2016, 27). 


\section{NARRAR CON MOVIMIENTOS DE CÁMARA: A PROPÓSITO DE EL CURA Y LA SUCIA}

En un tiempo en que conviven diversas visiones e intereses estéticos, Byung-Chul Han $(2018,11)$ advierte que suelen primar en la sociedad actual convenciones que se inclinan por lo "pulido", "lo pulcro" y "lo impecable" como señales de identidad artística. Sin embargo, Nadine Alemán apuesta por lo contrario en los veintiséis relatos que componen El cura y la sucia (2012).

Desde su Patagonia natal, pareciese que el viento, la lejanía y la aridez de la planicie contasen historias alucinatorias de personajes que narran sus aciertos, contradicciones, deseos, ingenuidad, locura, secreto, arrogancia, altanería y ruindad.

El eje articulador de este volumen de cuentos es, a simple vista, el laberinto, que, si bien nos despierta de inmediato la asociación borgiana, se caracteriza, en este caso, por construir una percepción de lo humano en el que se difuminan los límites de la imagen y la palabra. Al profundizar en ellos, los cuentos se pueden agrupar en tres grupos.

Al primero pertenecen los cuentos conformados por historias surrealistas en las cuales el inconsciente y el sueño alternan con la descripción de los ambientes, al modo de una cuidada dirección de arte. En el conjunto se enuncian elementos escenográficos de hermosos decorados, recurriendo a "materiales nobles". Desde ahí se erige un trasfondo glamuroso que da paso al ingenio estilístico y a la experimentación matizada con ironía y humor:

Con su voz de cantante pretendida, la Rosanafalasca sentencia por teléfono: si no nos reincorporan a nuestro antiguo trabajo, inauguraremos esta tarde el Festival de ácido muriático y aluminio apuntado a la Galería Stefanyk... esto terminará con sus preciadas piezas decimonónicas... la prensa está avisada, la rancia vanguardia arde de curiosidad, ustedes sabrán [“Muriatic \& Aluminium festival”] (Alemán, 2012, 24). 3

Del atrevimiento creativo resulta un exquisito imaginario que da vida a las historias narradas y sugeridas, a la par que deja en evidencia la experimentación que surge a partir de los títulos que comprenden este primer grupo: "Temor anfibio de madre e hijo", "Muriatic \& Aluminium Festival”, "Almuerzo fino en el desarmadero Bügel Brett”, "Bacteriana”, "Al fondo los reptiles" y "Tarde mística”. Basta citar algunos párrafos para ilustrarlo: "Encontré tres palabras para jugar hoy. Exacto. Excéntrico. Extremo. Miles de posibilidades de palabras que pueden asociarse de algún modo. Tantos años los míos en este estudio tan inútil como interesante" [“Temor anfibio de madre e hijo"] (Alemán, 2012, 9). O bien:

El Jefe dice que todos los niños somos haraganes en el mundo intelectual, que el trabajo de los padres - afirma - es quitarles la mala costumbre y el de las madres controlar que sea efectuado. Siempre imagino qué pensarían los familiares más cercanos. La gente se acostumbra a las cosas más extrañas cuando son frecuentes. Muchos de ellos todavía buscan

\footnotetext{
${ }^{3}$ Las cursivas son de la autora.
} 
rastros científicos para entender nuestra desaparición. Es más un pasatiempo de ricos que un interés real sobre nuestra historia [“Temor anfibio de madre e hijo”] (Alemán, 2012, 9).

El segundo grupo está compuesto por relatos cuya descripción espacial la conforman decorados que se alejan de la grandeza de los anteriores para dar paso a la etopeya. Por ejemplo, en "Huevos, agua, san Cono", se desarrolla la historia de un hombre al cual se le anuncia en sueños un tablero de lotería que definirá su modo de ser, pensar y actuar en el mundo. También ocurre en "Muerte la luz" y "Fátima Doris Lareti”, cuyas tramas giran en torno a la justificación de un fracaso:

Me parece increíble verte ese cuerpo tan trabajado, a tu gusto, tan logrado a fuerza de voluntad. Hasta parecés más alta. Y tu piel, tu rostro. Te miro y tenés los ojos afilados, la boca rigurosa. Tu pierna va tan alto... Te hace más decidida, Fátima. Te veo y comprendo que jamás retrocederías ante nada. Ahora menos que nunca. Como esa vez que te pusiste el vestido rojo y blanco para el baile de egresados. Todas las chicas de negro, de bordó, yo de azul. Tu vestido, de rojo y blanco. Ay, Fátima Doris! Qué locura la tuya, qué inconsciencia más acertada [“Fátima Doris Lareti”] (Alemán, 2012, 27).

En la conformación del tercer grupo, destaca un conjunto de cuentos breves en que los lugares comunes son más sencillos de digerir. En ellos, los personajes actúan en un ambiente natural y se convierten en pequeñas piezas que reconocen, desde su aparente inmaterialidad, su pequeñez ante paisajes que los superan por magnificentes y encandilantes. Sus personajes se desenvuelven de manera absurda, causando incluso la risa. Esto ocurre, a modo de ejemplo, en los habitantes del pueblo de "Paso Alto Discriminatoria" y en "La invasión de la señora Grimaraes”, donde se desdibuja la personalidad de un hombre solitario que inventa otra manera de amar:

En la marisquería me di cuenta de que era ella. Pensé durante semanas en algún truco para captar su mirada que siempre se bifurcaba sin alcanzarme. Mi paraíso científico se agrió antes de verla otra vez y saber más de la señora Grimaraes. Cuarenta y cuatro noches regresé a casa dejando encendida la luz del laboratorio, como venganza. Observé la gente que con ridícula valentía entraba a la escuela de baile. No salí a ahogarme en alcohol porque el asma me ata a la cinematográfica posibilidad del ridículo en los clubes nocturnos. Tuve la intención de enamorarme de ella. La deseo y apoyo mi trasero sobre esa verdad, entornando los ojos afuera de ese bar al que no me atrevo a entrar (Alemán, 2012, 30).

Similar característica se comprueba en "La mitrídates Azumendi", relato en el que un grupo de ancianas se traslada en un bus de viaje de jubilados, aunque ignoran que el final que les espera es el abandono. La narración se construye en torno a una atmósfera que suscita a la vez tristeza y ternura, develando una visión crítica sobre el maltrato que las personas reciben en la vejez y su consiguiente invisibilización social. Luego sumamos "Discusión vitalicia", donde unos locos artistas inventan una nueva obra circense en medio de la desértica Patagonia. Aquí se comprueba cómo los recursos del canto y el baile son esenciales para 
descubrir la imaginería del relato, la configuración de los personajes y el efecto performático: "Es que yo canto porque me gusta [...] Es una canción echada al mundo, cada uno la convierte y se transforma en ella, como yo que me convertiré en la Isidora Duncan más austral del mundo cuando salgamos de gira con mi 'danza central del cabello en la rueda”' (Alemán, 2012, 98). 4

Como se observa en la cita anterior, la práctica del canto configura un modo de ser del personaje cuya finalidad es definir su propia naturaleza desde la ritualidad de la transformación en un paralelo intertextual que combina identidad, entorno patagónico y performancia.

Más adelante aparece el delicioso momento de los tullidos perversos, presentes en "Faltan perros”, cuya perturbadora idea del incesto como parte del vínculo de dos hermanos obsesivos superpone planos discursivos e interpretativos: "Plinio y yo roímos la cena en perfecta comunión. Me gustó mucho rozar con mi pie desnudo sus piernas e intentar sacarme la duda protésica. Nos asumimos a una conducta homoerótica por venganza” (Alemán, 2012, 42). También sucede algo similar con los personajes pendencieros y vengativos de "Tres calambres y aspas puntiagudas", "El tímido rayo y su lento girar" y "Huesos de pájaro".

Es importante mencionar, además, los personajes fundados en el padecimiento y la pérdida. La voz narrativa se conduele con la construcción discursiva que desdibujan los padres de "Macedonia subhumana", quienes coinciden en un restaurante con los asesinos de su hijo. Se trata, en definitiva, de personajes atrapados en una desgracia y que ya no tienen nada que perder. Así se enuncia en el relato:

No sé si pasé de ver su cuerpo verdoso por la muerte por escape de gas. La voz de la madre de Laurita no me hirió como a Alejandro; no la abracé ni me unté en su dolor. Gabriela sacó el portarretrato con la foto de los chicos del living, le pedí expresamente que lo hiciera. Siempre me han conmovido más las imágenes que el sonido, de ahí que llorar o maldecir no significan nada para mí (Alemán, 2012, 77).

Entre los personajes que no tienen nada que perder, encuentran su propio espacio los marineros homosexuales de "Réplica y explosión de la quietud", pues se aman tanto que terminan haciendo que el narrador admire los recursos que desarrollan para finalizar sus días en una isla estereotipadamente paradisíaca. Es ahí donde disfrutan juntos como si se tratara de una venganza contra el mundo que los rechaza: "Lo observo hace tres horas, nunca pensé en volver a verlo, menos en esta pequeña isla flotante japonesa que se mece con cada sismo que justifica el Cinturón de Fuego del Pacífico. Es más valiente de lo que creí, desafía su propio sino y acaba de comprar una hamaca paraguaya verde con flores" (Alemán, 2012, 53).

A este grupo se suma la muchacha secuestrada por el oscuro mundo de la prostitución, mundo del que decide escapar en una estación de servicio camino a Asunción del Paraguay, en el relato "En Asunción venció la novia rusa". Pese a que ella sabe que lo que le espera es

\footnotetext{
4 Las cursivas son de la autora.
} 
peor que lo vivido, decide jugarse la vida en la escapatoria final. Lo mismo ocurre en "La creencia de la hija", historia en la que un padre intenta proteger a su hija, una niña santa abandonada por su madre, que tiene visiones apocalípticas y necesita la energía de los árboles para sobrevivir. En suma, son seres que se aferran a lo que tienen, y esa es su convicción.

Finalmente, y a la manera de un descanso de antesala, se configuran personajes de una teatralidad evidente, como la mujer sucia, extrañamente seductora, y el sacerdote anticuado con pretensiones de atleta olímpico en "El salto invertido del cura y la sucia": "Resulta que yo tengo un gran sueño que quiero concretar y solo usted, hermano Kirill, puede acompañarme en esta cruzada de fe y sacrificio: quiero que me entrene para lograr una medalla en las Olimpiadas 1988. El extranjero queda atónito ante el pedido y con palabras entrecortadas se disculpa por no entender del todo la propuesta” (Alemán, 2012, 67).5 La situación narrativa, que bien podría estar en un plano del absurdo, media entre una dimensión espectacular que aporta la trama y una alusión metafórica al "personaje-actor", que sorprende e impacta cuando se manifiesta a través de diálogos y acciones, al igual que en el resto de los relatos.

La voz narrativa se transforma en una suerte de voz espía que escudriña en los inconfesables secretos de familia de personajes que transitan por las diferentes historias. Así, el secreto se convierte en la razón que los define como cínicos, insistentes, perversos, manipuladores, arrogantes, mediocres y complejos, que transforman sus vidas para complejizarlas.

\section{LAS HISTORIAS; LUEGO, LOS EFECTOS}

El asomo a las historias de Alemán sorprende como un guion al que se le exige que cautive desde la primera línea. Cada relato parte como si asistiéramos al inicio de una grabación, activada por una cámara encendida que abre la escena en el preciso estado de registro persuasivo de un momento narrativo único, que entreteje con gran dinamismo diálogos, escenas, imágenes y expresiones poéticas.

Ubicar la mirada conduce al narrador a transitar por historias pensadas como escenas, cuadros e imágenes audiovisuales cuyo efecto sensorial se completa en el lector, quien, a la manera de un espectador, participa sinestésicamente de la recepción de elaborados y aludidos detalles. En los cuentos de Alemán abundan ejemplos para describirlo: "Sabe usted, mi querida, es por la exquisita nimiedad del detalle por lo que trasnocho, como todos los mecánicos dentales" [“Muerte la luz”] (Alemán, 2012, 60), “A las armas las carga el diablo y las descarga el General Pettulini - dijo y cerró la puerta que reverberó infartante" ["Paso Alto Discriminatoria”] (Alemán, 2012, 92), ${ }^{6}$ o “-Fíjese si está en la lista —dice la recepcionista. Hoy tengo que tener una paciencia especial para fijarme en la lista, una pequeña pupa rosada asoma por mi ojo izquierdo y no me permite ver demasiado" ["El dulce ardor de

\footnotetext{
5 Las cursivas son de la autora.

${ }^{6}$ Las cursivas son de la autora.
} 
la cuncuna”] (Alemán, 2012, 102). Los detalles, entonces, aportan elementos de interpretación y provocación que mezclan realidad e irrealidad con el propósito de superar los límites de una visión unívoca del mundo para explorarlo desde nuevas formas de representación.

La exactitud contenida en cada inicio permite constatar que el entorno y las preocupaciones de los personajes están visualmente construidos por medio de la variedad de focalizaciones. Esta característica promueve la posibilidad de que se muestren tal cuales son, sin restarles misterio a las acciones narradas: "Me he vuelto impúdica. No pornográfica: impúdica. Impúdica con mis sensaciones, con mis fantasmas, con mi cuerpo. Ya no los escondo más" ["Una mujer digna”] (Alemán, 2006, 38). Así, un detalle expuesto puede, en un segundo, justificar acciones, declaraciones, juicios o pensamientos de personajes que se han liberado de ataduras y prejuicios socioculturales.

Al finalizar 17 simples cuentos, la autora sintetiza en el párrafo final del cuento "La piel" todas las tramas de los relatos que componen el conjunto de la obra, relacionándolas con el fin de componer una original articulación que confirma su organicidad y sentido de exploración creativa. La síntesis se convierte en una práctica discursiva que resignifica a los personajes y la escenificación donde transcurren los hechos narrados, para dar cuenta de que la suma de conflictos que animan las historias forma parte de un mismo cuerpo textual que contiene, de manera performática, la expresión de un sistema valórico, memorístico y subjetivo:

Una no verá más la vida a la luz de la libertad, ya nunca más. La otra sí tendrá licencia para unirse al mundo, permanecer en él, ensayar cotidianamente ser igual a los demás, a la mujer digna, al marido, al amante, al taxista, a la campesina que el viento castiga, a la niña del pueblo que guarda una vieja fotografía sepia. A la vieja, a la gata, a la periodista, al cajero que es agua, al redactor que busca trabajo. Al jardinero que huye, al chico que oculta piedras que brillan. $\mathrm{Al}$ que ve fantasmas, a la que prefiere no verlos, al que barre la entrada, a la que no puede matar un cordero. A la que espera casarse y a la que sueña con separarse. Se une a todos. Hay un solo lugar en donde los que sobreviven y los otros se separan es justamente donde unos se delatan y los otros simulan, se sostienen aquí, ocultando (Alemán, 2006, 70).

Lo anterior responde no solo al dominio que la escritora demuestra de la síntesis o de la mirada selectiva de aquello que conmueve e inquieta a las voces narrativas de la compilación de relatos, sino a una urgencia por contar lo esencial, en un tiempo restringido, con el propósito de retener el instante de la acción de los personajes. Por este motivo, Nieto destaca que la autora "siempre nos reserva una sorpresa para el último párrafo, siempre sorprende, siempre confirma que conoce de su historia más de lo que está diciendo” (Alemán, 2006, 2).

A nivel escritural, predomina la brevedad como rasgo distintivo. Al respecto, Cortázar sostiene que, en tanto síntesis y tensión, el cuento responde a la dicotomía estructurante de lo cerrado y abierto a la vez: cerrado, por su carácter esférico, y abierto cuando se trata de despertar "una serie de connotaciones de aperturas mentales y psíquicas" (Cortázar, 2013, 32). Así, la brevedad en 17 simples cuentos — que también comparte Nieto- no sorprende si se considera lo que, a su vez, Hebe Uhart sugiere cuando afirma que "al escribir no hay que 
dar mucha información, hay que eludir, sugerir, no explicitar" (Villanueva, 2018, 70). Este antecedente se comprueba en este pasaje de "El cordero": "Mientras veía afilar los cuchillos, traer el balde, a los perros que se acercaban esperando las sobras, el fuego lanzar chispas, y la estaca de fierro esperando ensartar tremendo manjar, me volvía loco por dentro" (Alemán, 2006, 32).

Otra singularidad radica en los efectos de raigambre sensorial que produce la voz narrativa. Se perciben en la escritura colores, movimientos corporales, sonidos, sensaciones que aportan información y simbolismo al asunto narrativo. En "La Aúca" cautiva la voz personificada de una yegua que pide auxilio al borde del camino para llamar la atención de alguien que pueda socorrer a su amo moribundo: "Yo me esperaba un chirlo, un huascazo con el fino rebenque. Ya me tenía acostumbrada el patrón” (Alemán, 2006, 21), y después el giro perceptual: "Despacito, con mi alma de yegua triste y resignada, la emprendí p'al alambrado, a esperar que alguien me viera desde el camino” (Alemán, 2006, 22). Al personificarse, la narración aborda la afectividad desde la perspectiva performática, es decir, desdibujando los límites de la naturaleza y los roles sociales de los personajes porque "lo que verdaderamente importa [a la performance] es que ponga al espectador de frente a su propia capacidad de transformación en hombre, mujer, pájaro, bruja, zapato o lo que sea” (Taylor, 2015, 58).

Similar efecto se advierte en los demás relatos, que transportan al lector de la mano de lo sensorial hacia otros lenguajes artísticos que devienen en performance. ¿Cómo lo logra? A través de una portabilidad creativa; en otras palabras, mediante un proceso narrativo en que el texto pasa a ser una excusa para decir algo que se realiza en la actividad lectora mediante la imaginación, porque ha sido aludido en una simbiosis entre escritura y expresión visual, entre palabra e imagen: "A su padre lo acuesta, lo levanta, calienta el agua en el tanque de la cocina a leña y le prepara el fuentón de lata para bañarlo. Y apaga las velas temprano para que Ella, la Muerte, si llega no lo vea” ["Bianca encierra”] (Alemán, 2006, 48).

\section{RASGOS PERFORMÁTICOS EN LOS CUENTOS DE ALEMÁN}

Los 17 simples cuentos adelantan algunas características de estilo de la cuentística de Alemán que también aparecen en El cura y la sucia: preferencia por los efectos poéticos más que por las temáticas, empleo de recursos del lenguaje audiovisual en la presentación de los espacios, captación de acciones y escenas de la vida cotidiana de los personajes como descripción de escenificaciones, alteración del orden secuencial narrativo y selección de acontecimientos desde enfoques subjetivos.

Dichos rasgos emparientan los cuentos con técnicas propias del documental. Siguiendo a López Izquierdo (2009), ambas compilaciones coinciden con las características de las tres grandes partes que estructuran la escritura de los guiones cinematográficos: 1) lo retórico ("escritura invisible o de cámara"); 2) lo poético ("guion como relato"), y 3) lo estético ("efecto ambiguo, sugestivo y enigmático”). Esto permite sostener que el mundo representado en la ficción proyecta efectos más cercanos a la performance, en su acepción de "lente 
metodológico", tras reunir palabra, cuerpo, potencial creativo e influencias de la escritura de guion en la serie de relatos.

El guion no solo es un soporte técnico-artístico para su virtual representación escénica, ni solo con el guion se escribe la potencial representación, sino que además ofrece libertad interpretativa, dejando vacíos que completa la imagen visual aludida y procesada por el lector, que es, en esencia, narrativa. Basta remitir el cuento "El salto invertido del cura y la sucia", donde es revelador el siguiente detalle expuesto: "El Padre Bono de Iutú dobla prolijamente el suéter tejido con mal gusto, rayas, círculos y rombos y lo guarda para disfrazarse de moderno con un blazer que se sacó de la colecta nacional de la semana pasada. Canchero con el saco a cuadros, toma su documento de identidad para ir a la municipalidad a pedir subsidio bajo un nombre falso" (Alemán, 2012, 65).

Asimismo, el denominar es crucial para el narrador, pues selecciona cuidadosamente el instante que sirve de entrada al hecho relatado como afirmación mediante un ingenioso diálogo, juego verbal, imagen de encuadre, juicio, canción o expresión que condense el sentido que anima a adentrarse en la realidad expuesta, sea desde la exposición o desde el ocultamiento.

Desde esta perspectiva, Hilde Domin afirma que "denominar" se asocia más bien al uso de la palabra poética que en "la realidad denominada solo se hará visible - y también asible, al menos por momentos- cuando primero sea decible y comunicable y se convierta en objeto de la comunicación, del diálogo indispensable” (1986, 27). Así, el arranque de las historias se ofrece al narrador como una oportunidad para mostrarlas como si fuesen grabadas con movimientos de cámara, aunque haciendo la salvedad de que la focalización no solo es externa.

En "El odiador de árboles", la serie de detalles demuestra que el recurso del guion se emplea en la entrada a la narración, porque en los guiones los personajes "no sienten", sino que se configuran, se mueven, buscan, hablan, dicen o están vestidos de tal o cual manera como reflejo de una realidad enunciada: "Es como esas actrices que dejan morir a un hijo de hambre y siguen yendo al gimnasio envueltas en calza, buzo, vincha y anteojos negros. No repara en nada, ni siquiera en su deformidad. El marido es un perchero al que le cuelga prendas imaginarias. Él se sacude, las prendas desaparecen y ella viene a mí como un faro moderno sin batería” [“El cura y la sucia”] (Alemán, 2012, 45).

En definitiva, nominar, sugerir y ocultar aparecen como claves de acceso para la configuración de un estilo poético que busca tensionar la palabra escrita y sugerir otros lenguajes como efecto del proceso lector. Se accede a escenas, momentos, cuerpos y voces que confirman que esta escritura no existe solo para enunciar mediante la construcción textual, sino para constituirse en el alma de una expresión cromática que ilumina zonas ocultas de los personajes y sus historias, evidenciando los siguientes rasgos característicos de lo performático como resultado del proceso de recepción:

7.1. Narrativa no lineal de imaginería poética. Las historias se presentan al lector como momentos únicos de asomo a la realidad de los personajes, lo que desencadena el extrañamiento. Este efecto permite sostener que no siguen un discurrir argumental lineal, de 
narración tradicional, porque importa más detenerse en un gesto, una imagen, un hecho particular, una afirmación o una declaración de principios, sin dejar de responder a una lógica narrativa de raíz poética: “Adoro que Onírica hable así. Me recuerda la mujer maga que jugaba con un pañuelo rojo delante de un teatro lleno y finalmente quedaba desnuda frente a todas esas personas boquiabiertas. - Detesto que me llamen Onírica. Eros, el burlado. Burlado al ser gestado” [“Bacteriana”] (Alemán, 2006, 12).

7.2. El narrador como guionista o camarógrafo. A partir del uso de todas las focalizaciones (cero, interna y externa), el narrador construye con precisión las historias a través de una cuidadosa selección de espacios, ambientes y acciones que derivan en un efecto de “escenificación literaria”. Este rasgo está presente en la mayoría de los cuentos, apoyado por la brevedad enunciativa y la fuerza expresiva de los distintos argumentos, induciendo el efecto que producirá la entrada visual a una escena específica. Leemos y recreamos visualmente pasajes, personajes y conflictos narrativos, a partir de un detalle que captura el interés y la atención. Por ejemplo, una sola imagen descrita puede convertir al lector en espectador: "Cada vez que iba o venía de la escuela, la puerta del departamento 202 se entreabría y nadie salía. De todos modos, yo me sentía observado. Había alguien que me miraba desde allí” [“El 202”] (Alemán, 2006, 23).

7.3. Relación entre la escritura del guion y la narrativa de los cuentos. La preferencia por los elementos compuestos por acontecimientos, personajes y objetos que definen al guion se patentiza en el modo de narrar las historias, especialmente cuando se trata de producir el efecto de presencia y representación del entorno inmediato en el que transcurren los hechos y se desarrollan: "A ella le salen plumas y el marido tiene un claro síndrome de Munchausen, y no vive sin el protagonismo penoso que le da su esposa enferma" ["El odiador de árboles”] (Alemán, 2012, 45), o "Con su voz de cantante pretendida, la Rosanafalasca sentencia por teléfono: Si no nos reincorporan a nuestro trabajo, inauguraremos esta tarde el Festival de ácido muriático y aluminio" [“Muriatic \& Aluminium Festival”] (Alemán, 2012, 24).

7.4. La emoción como hilo argumental de los relatos. La expresión de las emociones, posibles de evidenciarse en un acto performático, es sugerida en la narración a través del tratamiento psicológico de los personajes. Sus deseos, convicciones, conflictos internos y creencias forman parte de una compleja red de sentimientos que los impulsan y marcan su destino personal, transformándolo: "Estoy solito sentado aquí en el sótano, con el martillo en la mano, y tengo sangre pero no me duele nada. La sangre es de la cabeza del novio de la chica del segundo, que está tirado ahí, pero yo no me puedo mover a ayudarlo" [“Cortésmente”] (Alemán, 2006, 47).

7.5. Actitud provocativa de los personajes. La complejidad de los personajes provoca al lector y promueve, a la manera de un acto performático, una reacción. Su objetivo va más allá de la mera interpelación o la narración de hechos: esperan la reacción cómplice de quien se asoma a sus historias para enrostrarle que el ser humano transita por un laberinto letal sin escapatoria cuando se enfrenta la vida desde el cinismo, la insistencia, la perversión, la manipulación, la arrogancia y la mediocridad: “¿Cómo se atreven? Le Marchant se lleva la 
mano a la cabeza antes de largarse a llorar desconsoladamente porque no volverá a ser ministro. ¿No entienden que vamos a hacer una explosión? ¿No les importa la colección Domás Gardiner? ¿La media tonelada de plata cincelada que haremos volar por los aires?” [“Muriatic \& Aluminium Festival”] (Alemán, 2012, 24).

7.6. Búsqueda de la transformación humana a partir de la crítica y la denuncia sociales. Todo acto performático busca una toma de conciencia en el receptor, sobre todo cuando se trata de representar la realidad opresora para denunciarla. Para lograrlo, se recurre a recursos que lo impacten mediante la estimulación sensorial y el empleo de la palabra: "Siete guerras mundiales, doce estallidos de volcán, cuántas generaciones y nosotros disfrutando de uvas del siglo veinte [“Almuerzo fino en desarmadero Bügel Brett”] (Alemán, 2012, 35), o “-Somos tan estúpidos que ni siquiera podemos dormir-" [“Bacteriana”] (Alemán, 2012, 14).

7.7. El cuerpo como soporte controversial de la acción. El cuerpo, en cuanto espacio de intervención y presencia, no solo permite la visualización de su propia narrativa, sino que contribuye a la provocación cuando los personajes muestran sus perversiones a través de la ausencia de revisión de sus conductas, descontrolándose y superando todo límite: “Me imaginé lamiendo con deseo (y hasta con loco amor) las prótesis de Plinio, recorriendo con una caricia hipócrita un pedazo de silicona, titanio, acero o lo que fuese que conformara sus segmentos fantasmas" [“Faltan perros”] (Alemán, 2012, 43).

7.8. Ambientación de origen audiovisual para personajes escenificados. La grandeza y la pequeñez que embargan a los personajes se dibujan mediante el relato de sus historias en ambientes imaginarios descritos al modo de una fantástica dirección de arte: "Palmenia reemplaza en la coreografía a Colombina con la bandeja de medusas y todo se vuelve más romántico. Es bueno que el talento pueda olerse y verse en colores y texturas [“Almuerzo fino en el desarmadero Bügel Brett”] (Alemán, 2012, 35). El narrador es detallista para conseguir la recreación de las sensaciones que les producen los lugares y las cosas con las cuales conviven: "Inquieta en el corral lo vi venir, porque sentí que esa mañana era diferente. Se acercó despacito, con su paso tranquilo, tan moreno y tan callado. Con las botas viejas, el ponchito gris y un sombrero nuevo" ["La Aúca”] (Alemán, 2006, 21).

Se evidencia con claridad su interés por caracterizar a los personajes no solo desde una dimensión psicológica, sino que repara en particularidades como la vestimenta, los olores, los objetos, los puntos de vista que asumen y todo cuanto pueda hablar sobre ellos: "La antigüedad del edificio, sus paredes húmedas y su olor a encierro eran un componente extra que me hacía soñar con fantasmas y seres sobrenaturales que me atacarían en el pasillo de entrada cuando fuese a dejar la basura. Yo vivía mi mundo de fantasía y misterio, y el lugar lo propiciaba con su sordidez" [“El 202”] (Alemán, 2006, 23). También mediante la interpelación accedemos a la descripción de los personajes, ya sea que provenga de las emociones o desde el móvil de la envidia que justifica sus propios fracasos: "Estás hecha para el arte. Se te nota. Puedo ver en tu paso, en este momento, la historia de un país, de una situación, una ideología. Todo te atraviesa, puedo sentirlo" ["Fátima Doris Lareti”] (Alemán, 2012, 28). 
El rasgo performático de la ambientación, que incide en la construcción de situaciones y personajes, es distintivo de la escritura de guion porque da indicaciones que permiten imaginarlos según su naturaleza:

Es dulce y palpitante el trago que Gaspar escondió y con el que brindo todos los viernes para honrarlo. He pensado en escribirlo todo haciendo el intento de no revelar lo que ella me ocasiona. Aunque es posible que Onírica/Galatea fuese feliz si le describiera esto una noche entre velas, las adora casi tanto como a las bacterias, puedo olerlo la vez que entro en su cuarto [“Bacteriana”] (Alemán, 2012, 14).

7.9. La realidad como espectáculo vista desde una perspectiva crítica. El narrador utiliza variados recursos para develar el carácter espectacular de la realidad. Recurre al humor, a la ironía y al análisis psicológico como base de los relatos. Lo hace para ridiculizar los comportamientos de los personajes porque se siente atraído por la inocencia que subyace a toda ridiculez, revelando poses, actitudes, perfiles y grandezas que hablan de pequeñez en un mundo que cada vez vive más hacia afuera.

Lo anterior se comprueba en cuatro relatos de El cura y la sucia: 1) "Bacteriana”, cuento en el que un grupo de jóvenes opta por solventar sus vicios a expensas de sus propias familias; 2) "Una soprano ligera", relato en el que se muestra la radiografía de una familia que se esfuerza por aparentar lo que no es, condición que termina desarticulándola; 3) "Muerte la luz", historia de un personaje envidioso crónico que inventa pequeños atentados para vengarse de quien cree que lo opaca, y 4) "Muriatic \& Aluminium Festival”, historia en la que se cuenta la explosión de una galería de arte, causada por un grupo que decide destruirla tras ser despedido. Cada una de estas narraciones pone de manifiesto cómo lo absurdo puede estar presente en lo convencional.

7.10. El accionismo creativo como resistencia. El arte ha sido históricamente el espacio de reacción y resistencia ante la exclusión social, el dolor, la discriminación, la violencia y la deshumanización. Sus múltiples manifestaciones, a través de los lenguajes artísticos existentes, permiten que el discurso se convierta en denuncia para transformarse también en llamado, en toma de conciencia y en urgencia de cambio. Desde esta perspectiva más amplia, el conjunto de relatos de ambas obras narrativas cumple con creces dicha misión salvadora: "Durante los cuarenta años del pueblo nadie se había puesto zapatos de colores, ni había bailado, ni inflado globos. Ahora todo eso sucedía de repente. Entre coreografía y coreografía la gente se dio cuenta de que bailando a través del cañón podía huir" ["Paso Alto Discriminatoria”] (Alemán, 2012, 94).

Los rasgos enunciados anteriormente permiten establecer dos puntos focales para internarse en la narrativa de Nadine Alemán: la singularidad de su escritura que recuerda la "escritura de cámara" o "escritura invisible" del guion (López Izquierdo, 2009) y el abordaje de lo humano desde el secreto y la perversión que, si bien no reconoce en lo patagónico un carácter referencial inicial, proyecta algunos rasgos que lo trascienden, porque "la literatura 
patagónica, sus aldeanos y sus aldeas, y sus particularidades a investigar, existen como presencias reales, al igual que el mundo" (Mellado, 2015, 70).

Si en 17 simples cuentos el secreto motiva la acción, en El cura y la sucia ese mismo motor activa lo perverso. La perversión es vista como un deleite irreprimible que posee el ser humano cuando sabe que un final será inevitablemente trágico; pero que, pese a ello, se desliza fascinado hacia él. Ahí reside la perversión derivada del secreto de sus pensamientos y represiones como una suerte de salto y continuidad entre ambas obras. Desde ese lugar mental y físico se manifiestan la conducta, la autonegación y la imposibilidad de mirarse a sí mismos. Se trata, en esencia, de una especial construcción discursiva en la que se produce la sensación de navegar a través del descontrol, aun sabiendo las consecuencias que trae consigo la similitud entre paisaje, determinismo y argumento: "La sensación de inminente expansión de la pampa húmeda me incomoda. Vivir en un lugar montañoso te sume en una introspección constante. Nada va a aparecer. Ni a desaparecer tampoco" ["Macedonia subhumana”] (Alemán, 2012, 78).

\section{EXACTO, EXCÉNTRICO Y EXTREMO: TRES CLAVES PARA CONCLUIR}

La cita inicial que da título a este artículo contiene tres términos que sintetizan las claves para adentrarse en el imaginario narrativo de Nadine Alemán: exacto, pues da cuenta del rigor y la precisión estilística con que cada palabra es una pieza fundamental en los enunciados con que construyen los relatos, en especial en los diálogos que, a la manera del guion, los articulan; excéntrico, al calificar la configuración de personajes, acontecimientos y espacios; y extremo, ya que sintetiza la experiencia de los personajes en torno al secreto, la perversión y la influencia de lo patagónico como trasfondo de situaciones narrativas, espacios y contextos sociales extremos.

En la recepción literaria de 17 simples cuentos y El cura y la sucia, la palabra deviene en imagen y la imagen en corporalidad como resultado que reúne recursos multidisciplinarios en un mismo cuerpo textual interpretable. Sin narrativa no hay cuerpo; sin cuerpo no hay performance. El efecto performático, en definitiva, se completa en el proceso lector como resultado de la recepción literaria.

Finalmente, esta indagación aquí desarrollada contribuye, en parte, a la advertencia que manifestara en 2012 el poeta chubutense Vives acerca de la necesidad de una exégesis de la nueva literatura patagónica, que tiene en Nadine Alemán a una de sus representantes más sugerentes y creativas.

\section{REFERENCIAS BIBLIOGRÁFICAS}

ALEMÁn, N. 2006. 17 simples cuentos. Buenos Aires: De los cuatro vientos.

ALEMÁN, N. 2012. El cura y la sucia. Buenos Aires: Malaspina.

Austin, J. L. 1996. Cómo hacer cosas con palabras. Barcelona: Paidós. 
BitTAR, S., CASANI, S., Polli, V. y SAINT-ANDRÉ, E. 1996. "El imaginario patagónico en el contexto de la literatura hispanoamericana", CELEHIS: Revista del Centro de Letras Hispanoamericanas, 2, pp. 49-57. Disponible en: https://fh.mdp.edu.ar/revistas/index.php/ celehis/article/view/640/665.

BlAKE, C. 2016. "Secretos de infancia en ficciones argentinas", Catalejos, 1(2), pp. 16-29. Disponible en: https://fh.mdp.edu.ar/revistas/index.php/catalejos/article/view/1669/1682.

CARrasco BARranco, M. 2017. "Valores artísticos y experiencia estética”, en Pérez, F. (ed.), El valor del arte. Madrid: La balsa de la medusa, pp. 49-76.

CORTÁZAR, J. 2013. Clases de Literatura: Berkeley, 1980. Santiago de Chile: Alfaguara.

CULLER, J. 2014. Breve introducción a la teoría literaria. Barcelona: Austral.

DEBORD, G. 2014. La sociedad del espectáculo. Barcelona: Indómita.

DERRIDA, J. 1989. La escritura y la diferencia. Barcelona: Anthropos.

Domin, H. 1986. ¿Para qué la lírica hoy? Barcelona: Akal.

EAGLETON, T. 2016. Cómo leer literatura. Buenos Aires: Ariel.

GIRAUD, C. 2007. Acerca del secreto. Contribución a una sociología de la autoridad y del compromiso. Buenos Aires: Biblos.

HAN, B.-Ch. 2018. La salvación de lo bello. Barcelona: Herder.

INGARDEN, R. 2005. La comprehensión de la obra de arte literaria. México, D. F.: Universidad Iberoamericana.

ISER, W. 1989. "El proceso de lectura”, en Warning, R. (ed.), Estética de la recepción. Madrid: Visor, pp. 81-88.

JAUSS, H.-R. 2002. Pequeña apología de la experiencia estética. Barcelona: Paidós.

LÓPEZ IZQUIERDO, J. 2009. Teoría del guion cinematográfico. Lectura y escritura. Madrid: Síntesis.

Mellado, L. A. 2013. Cartografías literarias de la Patagonia en la narrativa argentina de los noventa. Tesis de Maestría. Universidad de Buenos Aires. Disponible en: http://repositorio.filo.uba.ar/handle/filodigital/2039.

Mellado, L. A. 2015. "La Patagonia como versión de una distancia", Alpha, 41, pp. 65-71. http://dx.doi.org/10.4067/So718-22012015000200006.

RAMíREZ, J. A. 1983. "La ciudad surrealista”, en Bonet Correa, A. (coord.), El surrealismo. Madrid: Cátedra, pp. 71-90.

SELDEN, R., WidDOWSON, P. y BROOKER, P. 2001. La teoría literaria contemporánea. Barcelona: Ariel.

SCHECHNER, R. 2006. Performance Studies: An Introduction. London: Routledge.

TAYLOR, D. 2015. Performance. Buenos Aires: Asunto Impreso.

TAYLOR, D. 2017. El archivo y el repertorio. La memoria cultural performática en las Américas. Santiago de Chile: Universidad Alberto Hurtado.

TAYlor, D. y Fuentes, M. 2011. Estudios avanzados de performance. México, D. F.: Fondo de Cultura Económica.

VillanueVA, L. 2018. Las clases de Hebe Uhart. Buenos Aires: Blatt \& Ríos.

VIVES, J. E. 2012. “¿Existe una literatura patagónica?”, Taringa!, 6 de septiembre, 5 párrs. Disponible en: https://www.taringa.net/+arte/existe-una-literatura-patagonica_vicx7. 


\section{NOTA SOBRE EL AUTOR}

Cristián Basso Benelli es Magíster en Literatura, con mención en Literatura Hispanoamericana y Chilena (Universidad de Chile), Licenciado en Educación y Profesor de Educación Media en Castellano (Universidad Católica Silva Henríquez). Trabaja como profesor asociado de literatura en el Departamento de Castellano de la Universidad Metropolitana de Ciencias de la Educación (Santiago de Chile), institución en la que, además, es miembro del Claustro Académico del programa de Magíster en Didáctica de la Lengua y la Literatura. Actualmente realiza su tesis doctoral sobre la obra de Gabriela Mistral. ORCID: 0000-0001-8927-841X 